\title{
Take-all Patch Suppression in Creeping Bentgrass with Manganese and Copper
}

\author{
W.J. Hill ${ }^{1}$, J.R. Heckman ${ }^{2}$, B.B. Clarke ${ }^{3}$, and J.A. Murphy ${ }^{4}$ \\ Plant Science and Plant Pathology Departments, Rutgers, The State University \\ of New Jersey, 59 Dudley Road, New Brunswick, NJ 08901-8520
}

Additional index words. manganese, copper, take-all patch, Mehlich-3, manganese availability index, Agrostis stolonifera, Gaeumannomyces graminis, disease, turfgrass

\begin{abstract}
Take-all patch, caused by Gaeumannomyces graminis (Sacc.) Arx. \& D. Olivier var. avenae (E.M. Turner) Dennis (Gga), is a disease of creeping bentgrass (Agrostis stolonifera Huds.), which most often is associated with golf courses. Synthesis of ligneous and phenolic compounds by plants requires adequate $\mathrm{Mn}^{+2}$ and $\mathrm{Cu}^{+2}$ nutrition and may be a factor in disease resistance. An experiment was conducted on a creeping bentgrass fairway naturally infested with $G g a$ to determine if foliar applications of $\mathrm{Mn}^{+2}(1.02$ and $2.04 \mathrm{~kg} \cdot \mathrm{ha}^{-1}$ per application $)$ and $\mathrm{Cu}^{+2}\left(0.68 \mathrm{~kg} \cdot \mathrm{ha}^{-1}\right.$ per application) would reduce take-all severity. Prior to initiating treatments, soil pH was 6.4 and Mehlich-3 extractable $\mathrm{Mn}^{+2}$ and $\mathrm{Cu}^{+2}$ were $5 \mathrm{mg} \cdot \mathrm{kg}^{-1}$ and $1.7 \mathrm{mg} \cdot \mathrm{kg}^{-1}$, respectively. Manganese and copper sulfate treatments were initiated in July 1995 and foliarly applied every 4 weeks through 1997 with the exception of December, January, and February. Disease incidence was decreased from $20 \%$ on untreated turf to $5 \%$ with the high rate of $\mathrm{MnSO}_{4}$. For both years, turf treated with the high rate of $\mathrm{Mn}^{+2}$ had less disease than turf receiving the low rate of $\mathrm{Mn}^{+2}$. The application of $\mathrm{CuSO}_{4}$, however, did not influence disease development.
\end{abstract}

Take-all patch is caused by Gaeumannomyces graminis (Sacc.) Arx. \& D. Olivier var. avenae (E.M. Turner) Dennis $(\mathrm{Gga})$, and is primarily a disease of Agrostis spp. A related organism, Gaeumannomyces graminis (Sacc.) Arx. \& D. Olivier var. tritici $(G g t)$, is a serious root disease of wheat (Triticum aestivum L. em. Thell). Garrett (1981) reported that the disease could be effectively suppressed by mineral nutrition and soil management practices that lower soil $\mathrm{pH}$. The optimum $\mathrm{pH}$ for the growth of Ggt is 7.0 (Marschner, 1995). The severity of wheat takeall is influenced by $\mathrm{Mn}^{+2}$ availability in the rhizosphere and the $\mathrm{Mn}^{+2}$ concentration in roots (Huber and Wilhelm, 1988). Soil application of $\mathrm{Mn}^{+2}$ fertilizers helps to suppress wheat take-all on non-calcareous soils. In high

Received for publication 6 Nov. 1998. Accepted for publication 18 Feb. 1999. The research reported in this publication was supported by the New Jersey Agricultural Experiment Station Project No. D12177-9-98, and the Center for Turfgrass Science. Use of trade names does not imply endorsement of the products named nor criticism of similar ones not named. We appreciate the technical assistance of Dennis Haines and Wayne Anastasia. The cost of publishing this paper was defrayed in part by the payment of page charges. Under postal regulations, this paper therefore must be hereby marked advertisement solely to indicate this fact.

${ }^{1}$ Graduate Student in Plant Science and Technology Program. Present address: Lidochem, Inc. 20 Village Court, Hazlet, NJ 07730. E-mail: whlidochem@monmouth.com

${ }^{2}$ Specialist in Soil Fertility.

${ }^{3}$ Specialist in Plant Pathology.

${ }^{4}$ Specialist in Turf Management.
$\mathrm{pH}$ soils, $\mathrm{Mn}^{+2}$ is rapidly oxidized and made unavailable for plant uptake. Supplying N fertilizers in the ammonium form helps to lower soil $\mathrm{pH}$ and increase $\mathrm{Mn}^{+2}$ availability (Thompson et al., 1995). Soil application of $\mathrm{Cu}^{+2}$ also helps to reduce take-all of wheat grown on soil deficient in copper (Gardner and Flynn, 1988).

Applications of manganese and copper are thought to increase the plant's resistance to disease through utilization of these elements in the increased synthesis of phenolic and ligneous compounds. These compounds may serve as chemical barriers in plants to increase take-all resistance of wheat, even in soils adequately supplied with $\mathrm{Mn}^{+2}$ and $\mathrm{Cu}^{+2}$ (Graham and Rovira, 1984). The objective of this study was to determine the effect of $\mathrm{Mn}^{+2}$ and $\mathrm{Cu}^{+2}$ fertilization on the control of take-all patch of creeping bentgrass. More emphasis (two rates) was placed on manganese applications since there was more evidence in the literature to suggest that $\mathrm{Mn}^{+2}$ would have an effect on take-all.

\section{Materials and Methods}

An experiment was conducted on the third fairway of the Metedeconk National Golf Course in Jackson, N.J., where the creeping bentgrass turf ('Penncross' and 'Penneagle') was known to be infested with Gga. The fairway was established on a modified Lakehurst sand (mesic-coated Haplaquodic quartzipsamment) soil 10 years prior to the initiation of the experiment. The experimental area was maintained under normal fairway management throughout the duration of the study. The golf course crew used an 11-mm mowing height and clippings were removed. Applications of a $16 \mathrm{~N}-2 \mathrm{P}-7 \mathrm{~K}$ fertilizer, which contained ammonium phosphate, ammonium sulfate, potassium chloride, iron sulfate, and iron oxide as nutrient sources, were made monthly for a yearly total of $146 \mathrm{~kg} \cdot \mathrm{ha}^{-1} \mathrm{~N}$.

The $\mathrm{Mn}^{+2}$ and $\mathrm{Cu}^{+2}$ fertilizer treatments listed in Table 1 were initially applied on 27 July 1995, and with the exception of December, January, and February were applied every 4 weeks throughout 1996 and 1997. Commercial sources of manganese and copper, dissolved in $1 \mathrm{~L}$ of water and sprayed over $4.3-\mathrm{m}$ $\times 6.1-\mathrm{m}$ plots with a backpack sprayer calibrated to deliver $374 \mathrm{~L} \cdot \mathrm{ha}^{-1}$. The turf was irrigated with $\approx 1 / 3 \mathrm{~cm}$ of water after treatments were applied on hot sunny days to reduce the potential for foliar injury. Initial treatment rates $\left(1.53\right.$ and $3.05 \mathrm{~kg} \cdot \mathrm{ha}^{-1} \mathrm{Mn}$ per application; $1.02 \mathrm{~kg} \cdot \mathrm{ha}^{-1} \mathrm{Cu}$ per application) were reduced by one-third as shown in Table 1 after the first application on 27 July 1995. This was due to concern by the golf course superintendent about the potential for foliar injury. The experimental design was a randomized complete block with six replications.

Composite soil samples of five cores ( 0 to $5 \mathrm{~cm}$ ) and the thatch were collected from each plot just prior to the application of treatments on 27 Mar. 1996 and 11 June 1997. Soil samples were analyzed for Mehlich-3 (Mehlich, 1984) extractable $\mathrm{Mn}^{+2}$ and $\mathrm{Cu}^{+2}$. Soil $\mathrm{pH}$ was determined using a 1 soil : 1 water (by volume) ratio. The $\mathrm{Mn}^{+2}$ availability index (MnAI) was used to determine the soil $\mathrm{Mn}^{+2}$ status (Mascagni and Cox, 1985). The MnAI is a function of both soil $\mathrm{pH}$ and $\mathrm{Mn}^{+2}$ extracted by the Mehlich-3 extractant: $\mathrm{M} 3 \mathrm{MnAI}=101.7$ $-15.2(\mathrm{pH})+\mathrm{M} 3 \mathrm{Mn}$ (no units).

The incidence of take-all patch was recorded on 30 May 1996 and 20 June 1997 to determine the effects of the treatments on symptom expression. Disease incidence was calculated from a grid that was placed over each plot. Cross marks falling on necrotic tissue were counted as disease. Incidence is reported as the percentage of the plot area that was affected by the take-all fungus. Statistical analyses of the disease data were performed using the GLM procedure of SAS.

Single degree of freedom contrasts also were evaluated to test treatment effects.

\section{Results and Discussion}

Take-all patch was observed each spring and disease ratings were taken on 30 May 1996 and 20 June 1997. There was no phytotoxicity observed for any of the treatments. The application of $\mathrm{Mn}^{+2}$ reduced disease severity in both years (Table 2). Plots treated with the high rate of $\mathrm{Mn}^{+2}$ exhibited less disease than turf receiving the low rate of $\mathrm{Mn}^{+2}$. In both years, disease incidence was decreased from $20 \%$ on untreated turf to $5 \%$ with the high rate of $\mathrm{Mn}^{+2}$. Treatment effects were apparent for the period of time that disease symptoms were expressed (late spring to mid summer). These findings suggest that $\mathrm{Mn}^{+2}$ may play a role in improving the resistance of creeping bentgrass against take-all. 
Table 1. Soil pH, Mehlich-3 extractable manganese and copper, and Mehlich-3 manganese availability index (M3MnI) as affected by application of $\mathrm{MnSO}_{4}$ and $\mathrm{CuSO}_{4}$

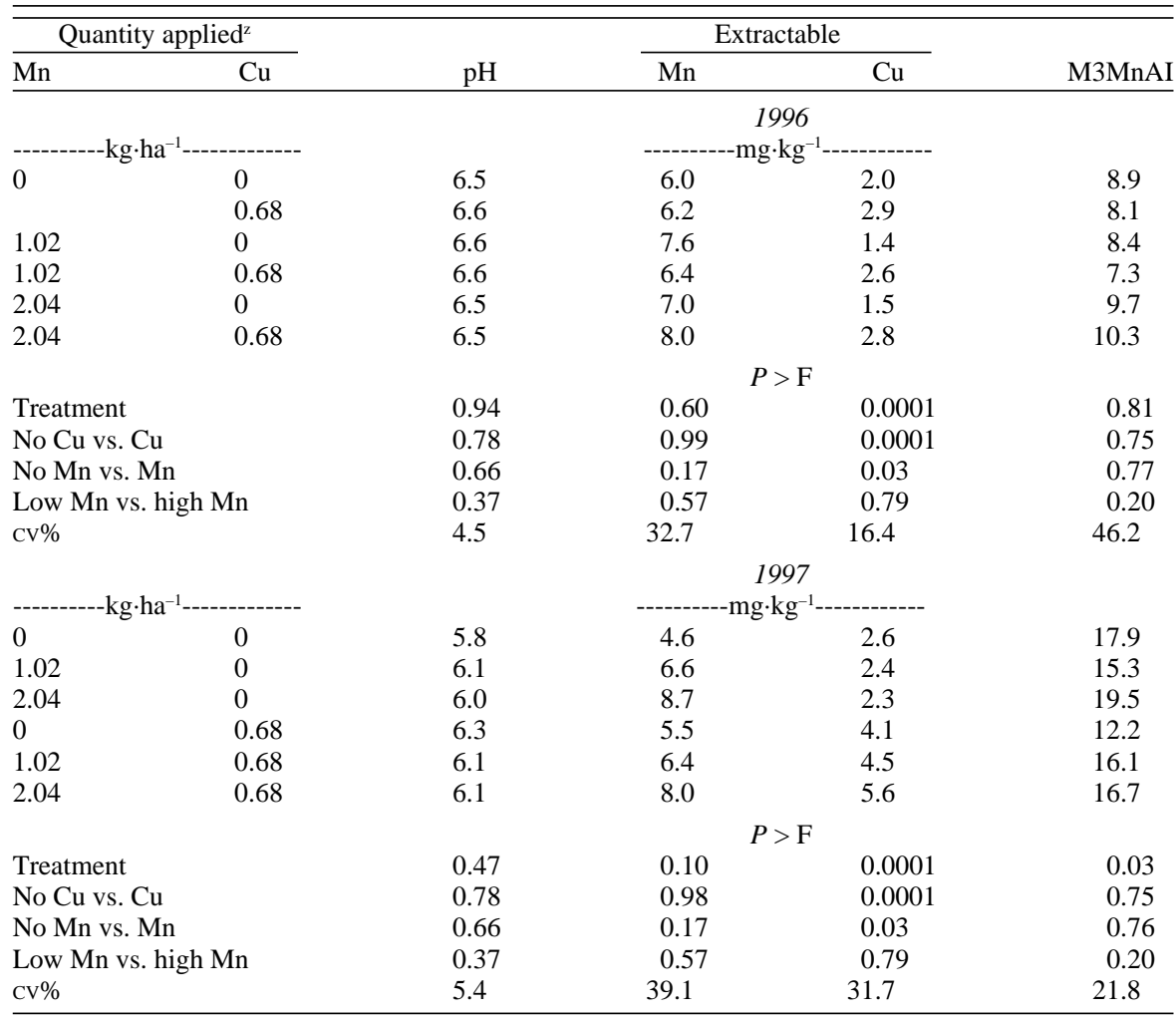

${ }^{2}$ Treatments applied every 4 weeks. The treatments listed are the reduced rates; original rates, were Mn: 1.53 and $3.05 \mathrm{~kg} \cdot \mathrm{ha}^{-1}, \mathrm{Cu}: 1.02 \mathrm{~kg} \cdot \mathrm{ha}^{-1}$

The application of $\mathrm{Cu}^{+2}$ alone or in conjunction with manganese did not affect disease development. The ineffectiveness of $\mathrm{Cu}^{+2}$ in reducing disease severity suggests that either $\mathrm{Cu}^{+2}$ was not limiting in this soil or that $\mathrm{Cu}^{+2}$ may be less involved in disease suppression than $\mathrm{Mn}^{+2}$. Initial soil testing in the experimental site found an extractable $\mathrm{Cu}^{+2}$ level of $1.7 \mathrm{mg} \cdot \mathrm{kg}^{-1}$ averaged across the plots. A soil test level of $0.4 \mathrm{mg} \cdot \mathrm{kg}^{-1}$ of $\mathrm{Cu}^{+2}$ is generally considered to be adequate for plant growth (Sims and Johnson, 1991). Thus, based upon the soil test data, $\mathrm{Cu}^{+2}$ was probably not a limiting plant nutrient at this site.

Soil tests performed on samples taken each spring during the time of disease appearance found no differences among treatments in soil $\mathrm{pH}$, extractable $\mathrm{Mn}^{+2}$, or the calculated Mehlich- $3 \mathrm{Mn}^{+2}$ availability index (M3MnAI) (Table 1). Applications of $\mathrm{Cu}^{+2}$, however, significantly increased extractable $\mathrm{Cu}^{+2}$ from soil in both years. The increase in soil test $\mathrm{Cu}^{+2}$ but not $\mathrm{Mn}^{+2}$ may be related to the chemistry of $\mathrm{Cu}^{+2}$ and $\mathrm{Mn}^{+2}$ reaction in soil. Alkaline soil reactions and soil $\mathrm{pH}$ levels near neutral favor the oxidation of soil $\mathrm{Mn}^{+2}$ in or applied to the soil. Gaeumannomyces graminis var. avenae is presumed to have the capacity to oxidize $\mathrm{Mn}^{2+}$ into plant-unavailable $\mathrm{Mn}^{3+}$ and/or $\mathrm{Mn}^{4+}$ in the rhizosphere (Huber and McCay-Buis, 1993). These processes may account for the inability to demonstrate buildup of $\mathrm{Mn}^{+2}$ in treated plots.

The M3MnAI has been used to predict manganese deficiencies in other crops. For soybean, [Glycine max (L.) Merrill], M3MnAI values of $<25$ predict that soybean will likely be deficient in $\mathrm{Mn}^{+2}$ (Mascagni and Cox, 1985) and values as low as 12 have been associated with $\mathrm{Mn}^{+2}$ deficiency in alfalfa (Heckman et al., 1993). Since take-all disease severity is thought to be related to manganese availability, the M3MnAI was used in an attempt to measure not only whether manganese was deficient, but also whether disease severity could be predicted in creeping bentgrass. In this study, the highest M3MnAI in 1996 was 10.3 and in 1997 was 19.5 . Since some symptoms of take-all were still evident even with the high $\mathrm{Mn}^{+2}$ rate, a critical level for M3MnAI could not be defined for creeping bentgrass. The soil test data from 1997 (Table 1) suggest, however, that for take-all suppression in creeping bentgrass the M3MnAI critical level may be $>19.5$.

Plant nutrition is an important consideration in the management of soilborne diseases. This study demonstrated a decrease in take-all patch severity in creeping bentgrass by using multiple applications of $\mathrm{Mn}^{+2}$ over a 2-year period. Because Gga probably has the capacity to oxidize applied $\mathrm{Mn}^{+2}$, the frequency of $\mathrm{Mn}^{+2}$ application may be an important factor in the use of $\mathrm{Mn}^{+2}$ for take-all management. Further research is needed to determine an optimum application frequency and rate of $\mathrm{Mn}^{+2}$ for the most effective suppression of take-all. Soil testing and $\mathrm{pH}$ management also should be a part of a take-all patch control program.
Table 2. Influence of manganese and copper fertilizer application on the incidence of take-all patch in a bentgrass fairway.

\begin{tabular}{|c|c|c|c|}
\hline \multicolumn{2}{|c|}{ Quantity applied $^{\mathrm{z}}$} & \multicolumn{2}{|c|}{ Disease incidence $^{y}$} \\
\hline $\mathrm{Mn}^{\mathrm{y}}$ & $\mathrm{Cu}^{\mathrm{y}}$ & 30 May 1996 & 20 Jun 1997 \\
\hline \multicolumn{2}{|c|}{------kg.ha-1------ } & \multicolumn{2}{|c|}{ 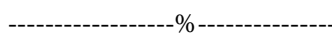 } \\
\hline 0 & 0 & 21 & 19 \\
\hline 1.02 & 0 & 15 & 10 \\
\hline 2.04 & 0 & 4 & 6 \\
\hline 0 & 0.68 & 18 & 21 \\
\hline 1.02 & 0.68 & 11 & 12 \\
\hline \multirow[t]{2}{*}{2.04} & 0.68 & 7 & 8 \\
\hline & & \multicolumn{2}{|c|}{$P>\mathrm{F}$} \\
\hline \multicolumn{2}{|c|}{ Treatment } & 0.02 & 0.0001 \\
\hline \multicolumn{2}{|c|}{ No Cu vs. $\mathrm{Cu}$} & 0.52 & 0.07 \\
\hline \multicolumn{2}{|c|}{ No Mn vs. Mn } & 0.004 & 0.0001 \\
\hline \multicolumn{4}{|c|}{ Low Mn vs. } \\
\hline \multicolumn{2}{|c|}{$\mathrm{Cu} \times \mathrm{Mn}$} & 0.77 & 0.81 \\
\hline \multicolumn{2}{|c|}{$\mathrm{Cu} \times \mathrm{Mn}$ rate } & 0.34 & 0.76 \\
\hline \multicolumn{2}{|l|}{$\mathrm{CV} \%$} & 70 & 28 \\
\hline
\end{tabular}

${ }^{\mathrm{z}}$ Amount applied every 4 weeks. The treatments listed are the reduced rates; original rates were $\mathrm{Mn}$ : 1.53 and $3.05 \mathrm{~kg} \cdot \mathrm{ha}^{-1}$, Cu: $1.02 \mathrm{~kg} \cdot \mathrm{ha}^{-1}$.

yercentage of the plot area affected.

\section{Literature Cited}

Gardner, W.K. and A. Flynn. 1988. The effect of gypsum on copper nutrition of wheat grown in marginally deficient soil. J. Plant Nutr. 11:475493.

Garrett, S.D. 1981. Introduction, p. 1-14. In: M.J.C. Asher and P.J. Shipton (eds.). Biology and control of take-all. Academic, New York.

Graham, R.D. and A.D. Rovira. 1984. A role for Mn in the resistance of wheat plants to take-all. Plant Soil 78:441-444.

Heckman, J.R., J.M. Ingerson-Mahar, D.L. Lee, and E.P. Prostko. 1993. Alfalfa responses to foliar and soil applications of manganese. Commun Soil Sci. Plant Anal. 24:559-572.

Huber, D.M. and T.S. McCay-Buis. 1993. A multiple component analysis of the take-all disease of cereals. Plant Dis. 77:437-447.

Huber, D.M. and N.S. Wilhelm. 1988. The role of manganese in resistance to plant diseases, $\mathrm{p}$. 155-173. In: R.D. Graham, R.J. Hannan, and N.C. Uren (eds.). Manganese in soils and plants. Kluwer Academic, Dordrecht, The Netherlands.

Marschner, H. 1995. Mineral nutrition of higher plants. 2nd ed. Academic, San Diego.

Mascagni, H.J., Jr. and F.R. Cox. 1985. Calibration of a manganese availability index for soybean soil test data. Soil Sci. Soc. Amer. J. 49:382386.

Mehlich, A. 1984. Mehlich 3 soil extractant: A modification of the Mehlich 2 extractant. Commun. Soil Sci. and Plant Anal. 15:14091416.

Sims, J.T. and G.V. Johnson. 1991. Micronutrient soil tests, p. 427-472. In: R.J. Luxmoore (ed.). Micronutrients in agriculture. Soil Sci. Soc. Amer., Madison, Wis.

Thompson, D.C., B.B Clarke, and J.R. Heckman. 1995. Nitrogen form and rate of nitrogen and chloride application for the control of summer patch disease in Kentucky bluegrass. Plant Dis. 79:51-56.

Wilhelm, N.S., R.D. Graham, and A.D. Rovira. 1990. Control of Mn status and infection rate by genotype of both host and pathogen in the wheat take-all interaction. Plant Soil 123:267-275. 